\title{
Species richness, abundance and vertical distribution of Copepods in Banda Sea, Indonesia
}

\author{
Hanung Agus Mulyadi ${ }^{1} *$ Abdul Basit $^{2}$, Idha Yulia Ikhsani ${ }^{3}$, and Malik Sudin Abdul ${ }^{3}$ \\ 1 Research Center for Deep Sea (RCDS)-Indonesian Institute of Sciences (LIPI), Plankton \\ Laboratory, Jl. Y. Syaranamual, Poka Ambon, Maluku, Indonesia \\ 2 RCDS-LIPI, Physical Oceanograpy Laboratory, Jl. Y. Syaranamual, Poka Ambon, Maluku, \\ Indonesia \\ 3 RCDS-LIPI, Chemical Oceanography Laboratory, Jl. Y. Syaranamual, Poka Ambon, Maluku, \\ Indonesia
}

\begin{abstract}
The aims of this research were to investigate the species richness and abundance of Copepods. Copepods were sampled using rosette sampler (surface, $25 \mathrm{~m}$ and $75 \mathrm{~m}$ ) on November $21^{\text {st }}-30^{\text {th }}$, 2013, from the Banda Sea. A total of 21 taxa of Copepods belonging to three orders were identified. Calanoid was identified as the most richness order, followed by Cyclopoid and Harpacticoid. The highest value of total abundance in the surface water is $121 \mathrm{ind} / 6 \mathrm{~L}$, in the $25 \mathrm{~m}$ of depth is $221 \mathrm{ind} / 6 \mathrm{~L}$, and in the $75 \mathrm{~m}$ of depth is $96 \mathrm{ind} / 6 \mathrm{~L}$. Acrocalanus longicornis is the most abundant taxa of Copepods, followed by Acartia bispinosa, and Subeucalanus mucronatus. The most predominant taxa of Acartia bispinosa, and Subeucalanus mucronatus showed a remarkable peak at $25 \mathrm{~m}$ layers.
\end{abstract}

\section{Introduction}

Plankton has an important role in the sustainability of fisheries resources in the Banda Sea. Some literature about oceanographic condition and plankton were conducted on Banda, such as Snellius Expedition that covered primary productivity [1]; oxygen condition [2]; and zooplankton abundance [3]. Copepods are the most important components of the zooplankton in marine ecosystems. They are the principal conduit for the flow of energy between primary producers and the higher trophic levels. Studies of zooplankton in coastal and even oceanic waters of the world have shown that copepods constitute the most important group in marine zooplankton communities [4]. The aims of this research were to investigate the species richness and abundance of copepods.

\section{Material and Methods}

This research was conducted from November $21^{\text {st }}-30^{\text {th }} 2013$ used Baruna Jaya VII RV. The sampling location was in the Banda Sea from $126.9^{\circ} \mathrm{E}$ to $130.1^{\circ} \mathrm{E}$ covered 19 stations

* Corresponding author: hanu001@lipi.go.id 
(Figure 1). Plankton samples were collected from six liters of seawater using rosette bottles. The plankton samples represent three different layers, surface $(0 \mathrm{~m}), 25 \mathrm{~m}$ and $75 \mathrm{~m}$. Formalin $4 \%$ was used for samples preservation. In the laboratory, water samples then filtered by using $100 \mathrm{~mm}$ filter. Identification processes followed several literatures $[5,6$, 7].

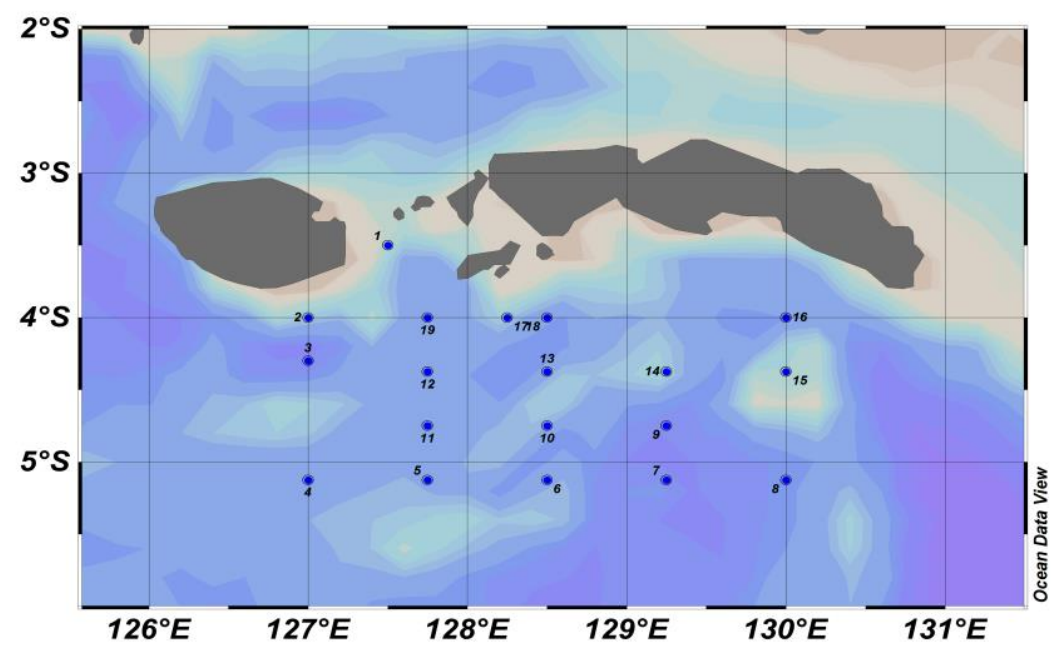

Fig 1. Sampling stations on Banda from $21^{\text {st }}-30^{\text {th }}$ November 2013.

Physical data such as temperature and salinity were measured in situ by using CTD (conductivity, temperature, depth) SBE-19 Plus. Onboard Baruna Jaya VII, the seawater samples were collected from discrete depth using rosette bottles $(12 \mathrm{~mL})$ that mounted on CTD carrousel. The sea water then subsampled for dissolved oxygen and nutrient content determination. Dissolved oxygen (DO) concentration was determined onboard using Winkler titration method [8]. The remain sea water then filtered through $0.45 \mu \mathrm{m}$ filters before transferred on polyethylene bottle and stored at $4^{\circ} \mathrm{C}$ for nutrient analysis. The nutrient concentration was determined at Chemistry Oceanography Laboratory of Research Center for Deep Sea by using Spectrophotometer UV-Visible Shimadzu 1700. Nitrate was analyzed by standard pink azo dye method, while phosphate using standard molybdenum blue method [9]. The software Ocean Data View (ODV) was used to visualize the crosssection of copepods and hydrological condition along sampling area [10].

\section{Results}

\subsection{Oceanographic factors}

Vertical distribution of sea surface temperature (SST) and sea surface salinity (SSS) in the Banda Sea from different layer were visualized on Figure 2. SST and SSS in Banda Sea ranges from $28.2^{\circ} \mathrm{C}-30.2^{\circ} \mathrm{C}$ and $33.35-34.85 \mathrm{psu}$, respectively. 

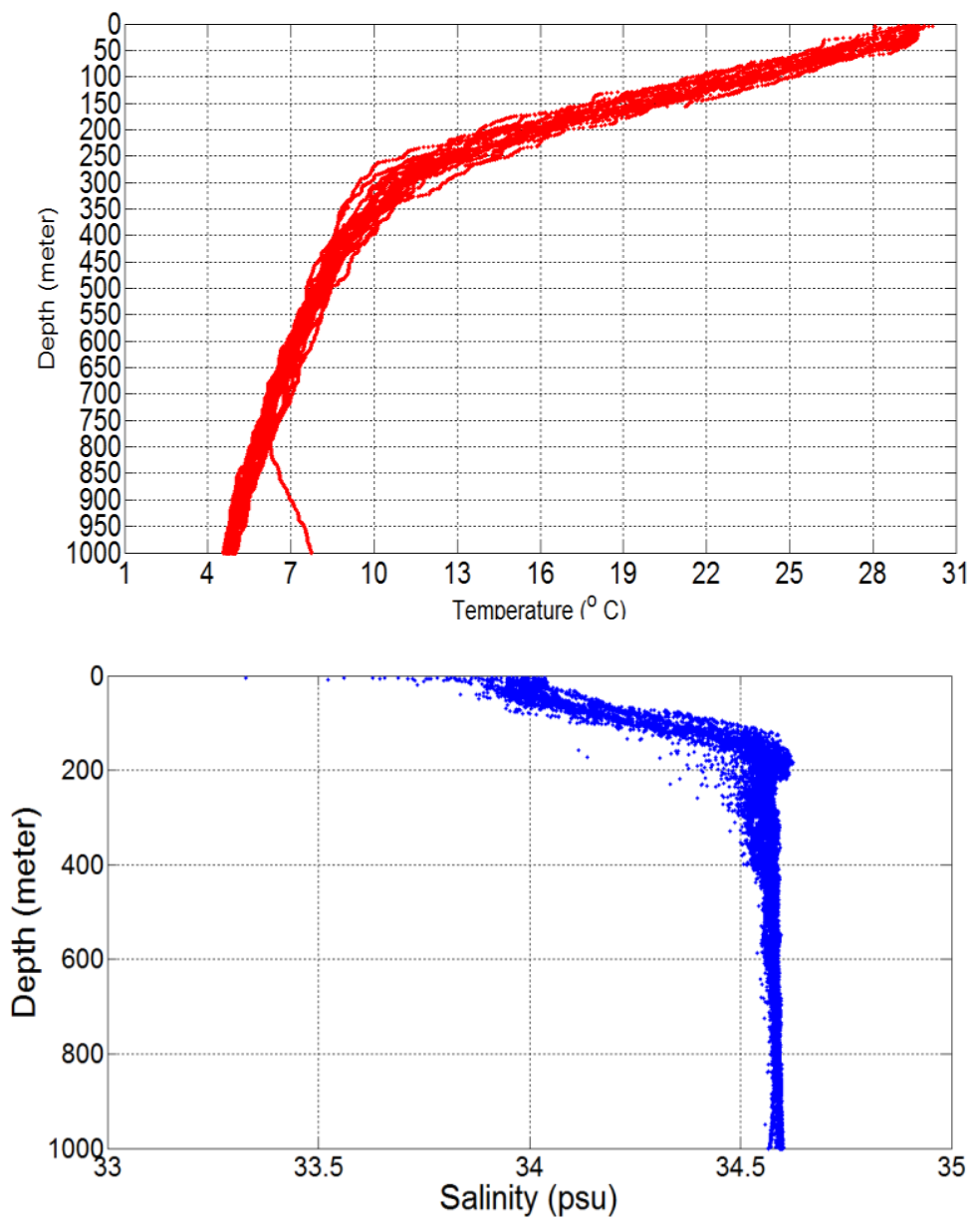

Fig 2. Vertical profile of SST (above) and salinity (below) in Banda Sea.

The distribution of dissolved oxygen (DO), nitrate, and phosphate from different depth were visualized on Figure 3. The concentration of DO in the surface, 50 and $75 \mathrm{~m}$ depth were in a range of 5.75-7.13; 4.69-6.91 and 4.077-5.87 $\mathrm{mgL}^{-1}$. The DO concentration tends to have the higher value on surface area than those on 25 or $75 \mathrm{~m}$ depth. For the nutrient, the concentration of nitrate and phosphate were in range of 0.0002-0.12 and 0.001-0.007 $\mathrm{mgL}^{-1}$ in surface area; $0.0002-0.05$ and $0.001-0.008 \mathrm{mgL}^{-1}$ in $25 \mathrm{~m}$ depth; $0.0002-0.11$ and $0.001-0.1 \mathrm{mgL}^{-1}$ in $75 \mathrm{~m}$ depth, respectively. 

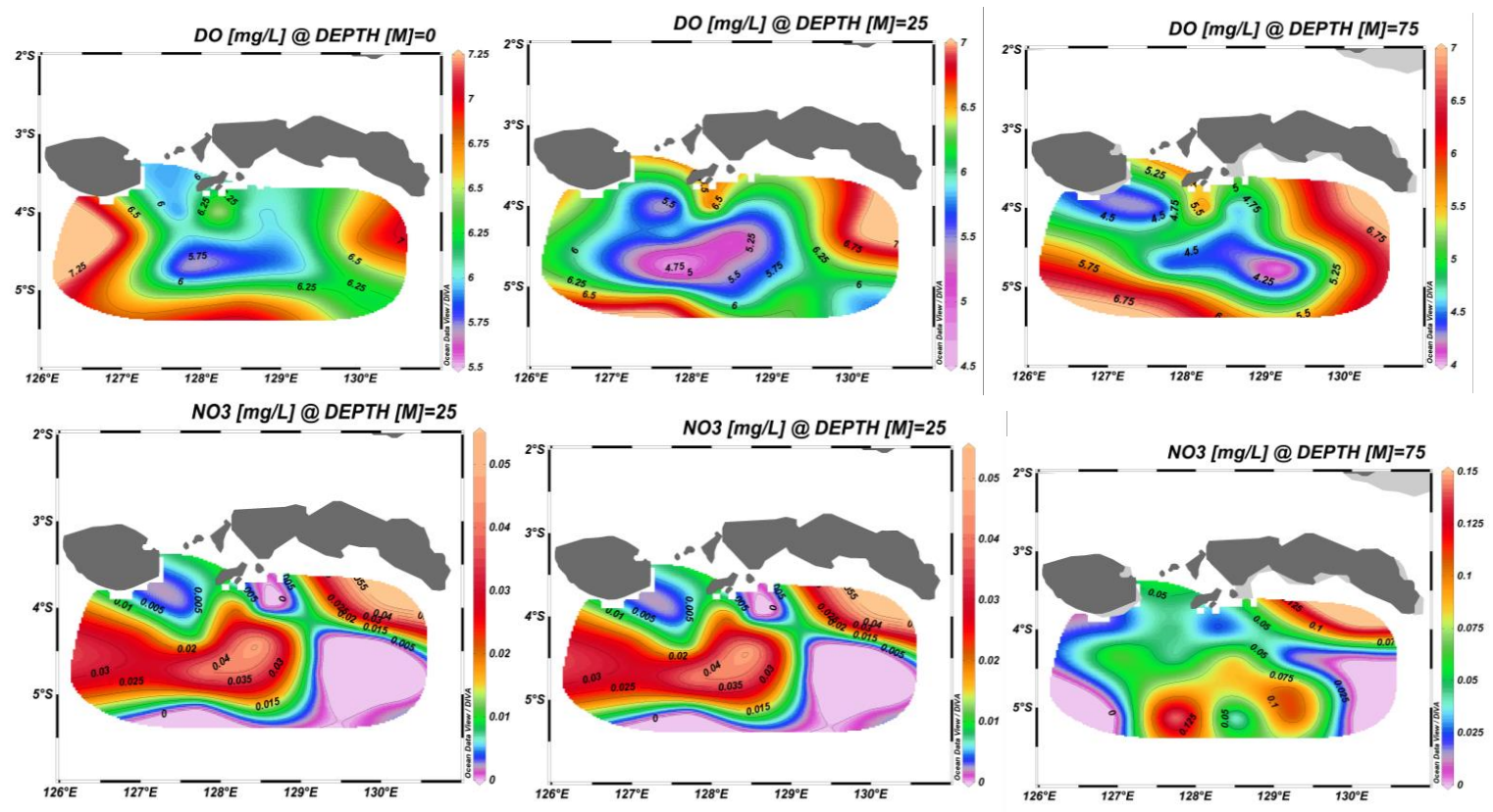


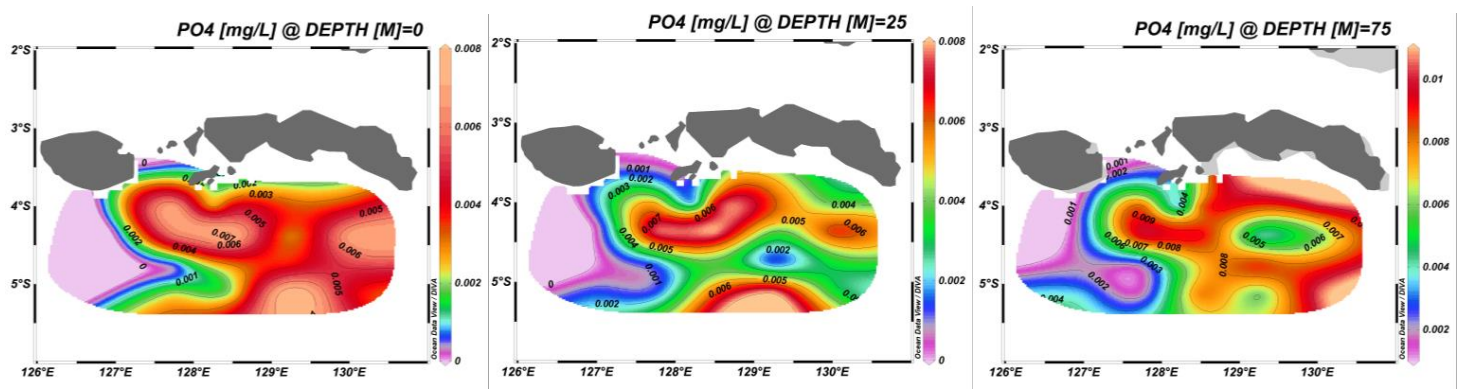

Fig 3. Oceanographic conditions in Banda Sea, $21^{\text {th }}-30^{\text {th }}$ November 2013 .

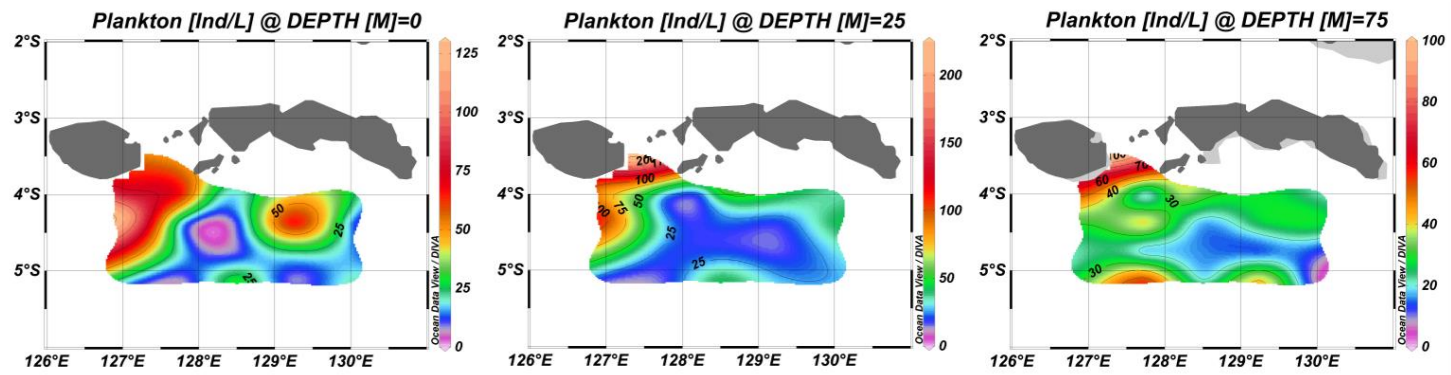

Fig 4. Abundance and vertical distribution of Copepods in Banda Sea. 


\subsection{Species richness}

A total of 21 copepods taxa were identified, predominantly to species, over the 18 sampling occasions during the study period. These included 13 calanoid, 5 cyclopoid, and 3 harpacticoid taxa. Detail of species richness in the Banda Sea shown in Table 1.

Tabel 1. Species richness in Banda Sea, $21^{\text {th }}-30^{\text {th }}$ November 2013.

\begin{tabular}{|c|c|c|}
\hline 1 & CALANOIDA & Candacia \\
\hline 2 & & Centropages furcatus \\
\hline 3 & & Acartia bispinosa \\
\hline 4 & & Pontella inflatodigitata \\
\hline 5 & & Temora $\mathrm{sp}$ \\
\hline 6 & & Tortanus gracilis \\
\hline 7 & & Labidocera caudata \\
\hline 8 & & Euchaeta longicornis \\
\hline 9 & & Scolecithrix sp \\
\hline 10 & & Paracalanus aculeatus \\
\hline 11 & & Acrocalanus longicornis \\
\hline 12 & & Rhincalanus nasutus \\
\hline 13 & & Subeucalanus mucronatus \\
\hline 14 & CYCLOPOIDA & Copilia quadrata \\
\hline 15 & & Saphirina sp \\
\hline 16 & & Oncaea sp \\
\hline 17 & & Oithona brevicornis \\
\hline 18 & & Corycaeus sp \\
\hline 19 & HARPACTICOIDA & Macrosetella $\mathrm{sp}$ \\
\hline 20 & & Clytemnestra $\mathrm{sp}$ \\
\hline 21 & & Euterpina sp \\
\hline
\end{tabular}

\subsection{Abundance and vertical distribution}

The abundance of copepods in the surface ranges from $7-121 \mathrm{ind} / 6 \mathrm{~L}$ with average $34 \pm 30.34 \mathrm{ind} / 6 \mathrm{~L}$, in 25 meters of depth ranging from $16-221 \mathrm{ind} / 6 \mathrm{~L}(44 \pm 48.43 \mathrm{ind} / 6 \mathrm{~L})$ and in the $75 \mathrm{~m}$ of depth ranging from $6-96 \mathrm{ind} / 6 \mathrm{~L}(32 \pm 20.04 \mathrm{ind} / 6 \mathrm{~L})$ Figure 4 . Acrocalanus longicornis is the most abundant taxa of Copepods, followed by Acartia bispinosa, and Subeucalanus mucronatus (Table 2).

Table 2. The most abundance taxa of Copepods (ind/6L) in Banda Sea.

\begin{tabular}{llll}
\hline No & Taxa & $\begin{array}{l}\text { Average } \\
\text { abundance } \\
\text { (ind/6L) }\end{array}$ \\
\hline 1 & CALANOIDA & Candacia sp & 1 \\
2 & & Centropages furcatus & 2 \\
\hline
\end{tabular}




\begin{tabular}{|c|c|c|c|}
\hline 3 & & Acartia bispinosa & 7 \\
\hline 4 & & Pontella inflatodigitata & 2 \\
\hline 5 & & Temora sp & 2 \\
\hline 6 & & Tortanus gracilis & 1 \\
\hline 7 & & Labidocera caudata & 2 \\
\hline 8 & & Euchaeta longicornis & 3 \\
\hline 9 & & Scolecithrix sp & 2 \\
\hline 10 & & Paracalanus aculeatus & 2 \\
\hline 11 & & Acrocalanus longicornis & 8 \\
\hline 12 & & Rhincalanus nasutus & 2 \\
\hline 13 & & Subeucalanus mucronatus & 6 \\
\hline 14 & CYCLOPOIDA & Copilia quadrata & 1 \\
\hline 15 & & Saphirina sp & 1 \\
\hline 16 & & Oncaea $\mathrm{sp}$ & 5 \\
\hline 17 & & Oithona brevicornis & 5 \\
\hline 18 & & Corycaeus $\mathrm{sp}$ & 3 \\
\hline 19 & HARPACTICOIDA & Macrosetella $\mathrm{sp}$ & 3 \\
\hline 20 & & Clytemnestra $\mathrm{sp}$ & 1 \\
\hline 21 & & Euterpina $\mathrm{sp}$ & 3 \\
\hline
\end{tabular}

Copepods have a high abundance in the Western area of Banda Sea rather than in Central and Eastern Banda Sea, mainly in Station 1,3 and 2 (figure 3). Station 1 has the highest average abundance $(123 \pm 88,008 \mathrm{ind} / 6 \mathrm{~L})$, followed by Station $3(86 \pm 46,68 \mathrm{ind} / 6 \mathrm{~L})$ and Station 2 (71 $\pm 17,35 \mathrm{ind} / 6 \mathrm{~L})$, respectively. The most predominant copepods of Acartia bispinosa, Acrocalanus longicornis and Subeucalanus mucronatus and showed a remarkable peak at $25 \mathrm{~m}$ layers (Figure 5).

Acartia bispinosa

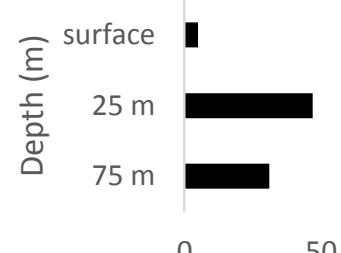

Abundance (ind/6L)
Acrocalanus longicornis

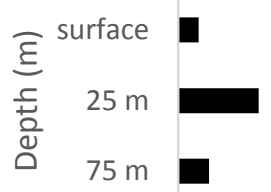

$0 \quad 50 \quad 100$
S. mucronatus

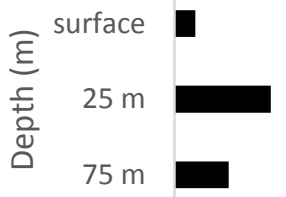

$\begin{array}{lll}0 & 20 & 40\end{array}$

Abundance (ind/6L)

Fig 5. Abundance of predominant taxa Acartia bispinosa, Acrocalanus longicornis and S. mucronatus (Station 1). 
Thermocline layer record on 200-500 m of depth and the halocline was occur in 100$200 \mathrm{~m}$ of depth. The physical conditions around the Banda Sea are influenced by monsoon $[11,12,13]$. The southeasterly winds generally expose the Banda Sea between May and October periods generating upwelling in this area. As consequence of this, the Sea Surface Temperature (SST) in the Banda Sea is relatively cold compared to the other periods. In this period, the SST varies between $25-28{ }^{\circ} \mathrm{C}$. In contrast, the downwelling is generally observed during the northwest monsoon (December - March) when the northwesterly winds expose the Banda Sea. The relative warm SST is generally found in this period varying between $28.5-30{ }^{\circ} \mathrm{C}$. The period between the two seasons (April and November) is called as the transition period. In this period, the winds start to change their directions. According to the result of concentration measurement, the nutrient was minimal in $25 \mathrm{~m}$ depth due to the most abundance of phytoplankton in this area. Nitrate was used by phytoplankton for photosynthesis processes, while phosphate was used either for photosynthesis or for tissue construction [14].

Our results show that species richness of copepods dominated by calanoid $(61.91 \%)$, followed by cyclopoid (23.81\%) and harpacticoid (14.29\%). The species richness in the Banda Sea is similar with other copepod community structure in Piru Bay [15]; and other territorial waters $[16,17]$. In the Western area of Banda Sea have the high abundance of copepods, it may be related with the nutrient upwelling. Nutrient upwelling has the hight contents of nitrate and phosphate. After that, nutrients will be utilized by phytoplankton. Further, zooplankton herbivore grazing on phytoplankton [18].

Copepods are known to vertically migrate even in the lower oxygen condition. In this study, the DO (dissolved oxygen) concentration in the Central of the Banda Sea more lower than in the Western and Eastern Banda Sea (Figure 3). It appears that the oxygen minimum concentration affected the distribution and abundance of copepods in the Banda Sea. The calanoid copepod Acartia tonsa identified at high abundance at a layer in well-oxygen concentration but absent at the same depths when oxygen dropped [19].

A large number of herbivorous copepods Acartia bispinosa, Acrocalanus longicornis and Subeucalanus mucronatus in most of station probably due to the higher abundance of phytoplankton. Grazing of herbivorous zooplankton more than $80 \%$ of phytoplankton production during summer [20]. Further, the feeding behaviour, as well as the food quantity and quality, are recognized factors that affect copepods growth [21].

\section{Conclusions}

Calanoid was identified as the most richness order, followed by Cyclopoid and Harpacticoid. Acrocalanus longicornis is the most abundant taxa of Copepods, followed by Acartia bispinosa, and Subeucalanus mucronatus. The most predominant taxa of Acartia bispinosa, and Subeucalanus mucronatus showed a remarkable peak at $25 \mathrm{~m}$ layer.

The authors would like to thanks Dr. Augy Syahailatua, M.Sc, the Director of Research Center for Deep Sea for the supports and opportunities to conduct the observation in the scheme of Banda Sea expedition. The surveys were funded by DIPA, provided by Indonesian Institute of Sciences in 2013. Special thanks are offered for plankton technicians, Salomy Hehakaya and La Imu for the determination analysis and the assistance in the field work, collecting samples.

\section{References}

1. W.W.W. Gieskies, G.W. Kraay, A. Nontji, D. Setiapermana, Sutomo, Neth. J. Sea. Res. 25 (4), 11 (1990)

2. $\quad$ S.B. Tijssen, M. Mulder, F.J. Wetsteyn, Neth. J. Sea Res. 25 (4), 15 (1990) 
3. M.A. Baars, A.B. Sutomo, S.S. Oosterhuis, O.H. Arinardi, Neth. J. Sea Res. 25 (4), 17 (1990)

4. J.T. Turner, Zool. Stud 43 (2), 12 (2004).

5. Mulyadi, Treubia 32, 167 (2002)

6. Mulyadi, Calanoid copepods in Indonesian Waters (Research Centre for Biology, Indonesian Institute of Sciences, (2004)

7. I.E. Yamaji, Illustrations of the marine plankton of Japan (1984)

8. M. Ehrhardt, K. Grasshoff, K. Kreming, T. Almgren, Methods of seawater analysis (Verlag Chemie Weinheim, 1983)

9. J.D.H. Strickland, T.R. Parsons. A practical handbook of seawater analysis (1972)

10. R. Schlitzer, Comp. and Geo. Sci. 28 (2002)

11. K. Wyrtki, Physical oceanography of Southeast Asian Waters, 2 (NAGA Rep, 1961)

12. A.L. Gordon, R.D. Susanto, Banda Sea surface-layer divergence, Ocean Dyn. 52 (2), 9 (2001)

13. R.D. Susanto, A. Ffield, A.L. Gordon, T.R. Adi, J.Geophys. Res. 117, 16(2012)

14. R. Chester, Marine geochemistry (1993)

15. H.A. Mulyadi, Prosiding seminar nasional III : hasil hasil penelitian perikanan dan kelautan FPIK UNDIP, 6 (2013)

16. C.A. Gaonkar, V. Khrisnamurthy, A.C. Anil, Environ. Monit. Assess. 168, 16 (2010)

17. H.M.M. Peralta, F. Md. Yusoff, Inter. J. Ecosystem. 5 (2), 5 (2015)

18. S. Gasparini, J. Castel, J. Plankton Res. 19, 14 (1999)

19. M.R. Roman, A.L. Gauzens, W.K. Rhinehart, J.R. White, Limnol. Oceanogr 38, 12 (1993)

20. G.B. Mc Manus, B.A. Costas, H.G. Dam, R.M. Lopes, S.A. Gaeta, S.M. Susini, C.H. Rosetta, Hydrobiologia 575, 13 (2006)

21. C.A. Vargas, R.A. Martinez, R. Escribano, N.A. Lagos, J. Mar. Biological Assoc. The U.K. 90 (6), 13 (2010) 